\title{
Macro and Micro-Nutrients of Azolla pinnata as a Soilless Growth Media
}

\section{Rosnah Shamsudin ${ }^{1,2 *}$, Nor A. A. Azhari', Susilawati Kasim ${ }^{3}$, \& Muhammad A. S. Rahmat $^{1}$}

${ }^{1}$ Department of Process and Food Engineering, Engineering Faculty, Universiti Putra Malaysia, 43400 Serdang, Selangor, Malaysia.

${ }^{2}$ Institute of Advanced Technology, Universiti Putra Malaysia, 43400 Serdang, Selangor, Malaysia.

${ }^{3}$ Department of Land Management, Agriculture Faculty, Universiti Putra Malaysia, 43400 Serdang, Malaysia.

\author{
*Corresponding author E-mail: rosnahs@ upm.edu.my \\ Received 19 September 2019; Accepted 29 September 2021; Available online 28 October 2021
}

\begin{abstract}
Azolla pinnata is a small floating fern which widely occurs in certain regions such as Southeast Asia. Azolla is utilized in the new plant research on the currently existing products for soilless growth media. Soilless growth media are an alternative component to replace soil for cultivation uses. In urbanization scenario nowadays, most of the flatten openarea soil is used for development, affecting the soil supply for plants. To introduce a new component such as the soilless growth media, it must have the same or more nutrients than soil or other existing soilless growth media. A study found that Azolla is used as a soilless growth media in the nursery for olive trees cultivation. According to the study, the nutrients obtained from Azolla are sufficient to replace soil as a growth media. In this experiment, the Single Dry Ashing, and Kjeldahl and Dummas methods were used to evaluate and compare both macro and micronutrients of Azolla to Midorie Pafcal and Jiffy-7 pallets. Based on the results, the values were $0.94 \%(\mathrm{~N}), 4352.00 \mathrm{ppm}(\mathrm{P})$, and $563.13 \mathrm{ppm}(\mathrm{K})$; compared to $1.35 \%(\mathrm{~N}), 377.13 \mathrm{ppm}(\mathrm{P}), 1512.33 \mathrm{ppm}(\mathrm{K})$; and $0 \%(\mathrm{~N}), 563.13 \mathrm{ppm}(\mathrm{P}), 1343.67 \mathrm{ppm}$ $(\mathrm{K})$, respectively. The results also showed the values of Copper $(\mathrm{Cu})$, Iron $(\mathrm{Fe})$, and Zinc $(\mathrm{Zn})$ for Azolla, Midorie Pafcal and Jiffy-7 samples were $15.33 \mathrm{ppm}(\mathrm{Cu}), 2579.67 \mathrm{ppm}(\mathrm{Fe})$, $93.63 \mathrm{ppm}(\mathrm{Zn}) ; 7.53 \mathrm{ppm}(\mathrm{Cu}), 9988.33 \mathrm{ppm}(\mathrm{Fe}), 26.77 \mathrm{ppm}(\mathrm{Zn})$; and $13.01 \mathrm{ppm}(\mathrm{Cu})$, $1150.30(\mathrm{Fe}), 12.40 \mathrm{ppm}(\mathrm{Zn})$, respectively. In conclusion, Azolla pinnata is capable of providing the nutrients required for a plant, making it suitable as a soilless growth media for all plants.
\end{abstract}

Keywords: Azolla pinnata, Soilless growth media, Macro and micro-nutrients.

\section{Introduction}

Azolla pinnata $\mathrm{R}$. Br. is a species of fern also known as a mosquito's fern. This fern is locally distributed in the native range of Africa, Madagascar, India, Southeast Asia, China, Japan, Malaysia, and the Philippines (Croft, 1986). It floats upon a water surface and potentially spreads quickly, covering an open area of the surface water. It can double its leaf area within seven days on an excellent condition of nutrient and temperature (Paul Brouwer et al., 2019). Azolla has been used for centuries in the industries, especially as a fertilizer in the rice production in Southeast 


\section{Shamsudin et al. / Basrah J. Agric. Sci., 34(Special Issue 1): 180-189, 2021}

Asia (Wagner, 1997; Paul Brouwer et. al., 2018). It contributes numerous benefits in paddy cultivation, which results in reducing the overall production costs for the cultivation of rice and increasing the yield of paddy (Ali \& Leeson, 1995). Furthermore, Azolla is also used as a feed product for livestock such as poultry, dairy, fishes, goats, sheep, and pigs. Numerous studies have been carried out for a more comprehensive development range of Azolla as a biofertilizer. Azolla possesses the required qualities for a green manure due to its fast growth, large biomass production, high in nitrogen, and ease to decompose. It is capable of absorbing atmospheric nitrogen directly through Anabaena via the biological nitrogen fixation whereas other plants tend to obtain their nitrogen by absorbing nitrogen from a complex compound in the soil through the roots (Soo et al., 2019).

Basically, the soil consists of nutrients such as nitrogen, phosphorus, calcium, and potassium which are suitable for plant growth. As the amount of nutrients reduces as a plant grows, the soil might loses from nutrient deficiency (Han \& Lee, 2005). The natural nutrient should be supplied. Thus, a growing media play an essential role to enrich the soil and replace the nitrogen lost, either from organic materials or inorganic substances, including the minerals made up of pure and inorganic chemicals.

Future agriculture introduces organic soilless media as an initiative to replace the existing soils as growing media. Peat, coir, and soft-wood pine bark are the common materials used as the growing media. The peat encompasses numerous types of plant materials that have been partially decomposed under anaerobic, waterlogged conditions (Bunt, 1988). While it is inevitable that certain problems will occur such as low re-wetting capacity (Michel, 2010), peats generally tend to possess excellent physical, chemical, and biological properties for plant growth (Robertson, 1993; Schmilewski, 2008; Krucker et al., 2010). General physical, chemical, and biological properties of coir have been widely reviewed (Prasad, 1997; Bragg, 1998; Schmilewski, 2008; Nichols, 2013). Chemical properties such as $\mathrm{pH}$ value, electric conductivity, cation exchange capacity, and nutrient availability have been measured across a diverse range of growing media as well (Lemaire, 1995; William R. Argo, 1998; Silber, 2008). If fewer nutrients were provided, the additional nutrient would be given through fertilizer additives (Bragg, 1998; Handreck \& Black, 1994). Most nutrients tend to be available within a narrow $\mathrm{pH}$ range value of 5.0- 5.5 (Lucas \& Davis, 1961). Most of the artificial and soilless growth media are formed by chemical products to maintain the health of the soil, and the organic products will then be produced.

Azolla is the new material being utilised in soilless growth media. Limited research is available to investigate the application of Azolla as soilless growth media. Based on previous study, Azolla was used as a growing media component in olive nurseries (Olea europaea L.) for containerized plants. Throughout this study, Azolla can remove the excessive values of phosphorus and nitrate, helping to improve the water quality (Petruccelli, et al., 2015). In addition to that, when Azolla was used as a growing media in the nursery of olive plants, the plants displayed linear growth and their total biomass production was greater than the control medium (Petruccelli et al., 2015). That research has indicated that Azolla might be a suitable component for olive plants grown in containers (Rafaela et al., 2015). Azolla is chosen as the main component of the new growth media initiative because it contains 


\section{Shamsudin et al. / Basrah J. Agric. Sci., 34(Special Issue 1): 180-189, 2021}

most of the macro and micro-nutrients needed by plants such $\mathrm{N}, \mathrm{P}, \mathrm{K}, \mathrm{Mg}, \mathrm{Ca}, \mathrm{Na}$ and others. In this study, two methods were used to achieve the aim of this research: Single Dry Ashing, and Kjeldahl and Dummas Methods. This research was to evaluate and compare both the macro and micronutrient of $A$. pinnata to Midorie Pafcal and Jiffy-7 pallets.

\section{Materials \& Methods}

\section{Sample preparation}

The raw A. pinnata was collected from vertical multilayer shelves from the Food Machinery Laboratory, Faculty of Engineering, UPM. Then, the collected Azolla was spread evenly at a designated place and dried under the sun for about four days. The initial weight of the raw Azolla was weighed.

\section{Single Dry Ashing Method}

The single dry ashing method was usually used to find the volume of total potassium, phosphorus, calcium, magnesium, sodium, iron, copper, zinc, and aluminium (Liu et al., 2019) of organic materials such as plant tissues, compost, peat soil and others. After four days, the raw Azolla was weighted to ensure that the volume of moisture content decreased or that it was completely dried. After that, the samples were placed in an oven at $60^{\circ} \mathrm{C}$ for 1 day ( 24 hours). Then the samples were cooled down in the desiccator. After that, 1 gram of dried sample was ground with a domestic blender (EBM-B1235 (IV) Blender, ELBA, Italy) and filtered through a $250 \mu \mathrm{m}$ filter sieve. The ground sample was then placed into a crucible on a muffle furnace (Salva FC-18, Salva, Moscow) at $300^{\circ} \mathrm{C}$ for 1 hour. After 1 hour, the temperature was raised to $520^{\circ} \mathrm{C}$ for the next 5 to 6 hours. After the sample was completely cooled down, the sample was taken out from the desiccator, and $10 \mathrm{ml}$ of distilled water and $2 \mathrm{ml}$ of concentrated hydrochloric acid $(\mathrm{HCl})$ was added to the sample. Then, the sample was evaporated in the fume chamber. Then, $10 \mathrm{ml}$ of $20 \%$ of nitric acid $\left(\mathrm{HNO}_{3}\right)$ (prepared by combining 1 liter of distilled water and $200 \mathrm{ml}$ nitric acid $\left(\mathrm{HNO}_{3}\right)$ into the sample and placing it in a water bath for 1 hour) was added. Finally, the sample was filtered through a Whatman filter into a volumetric flask to determine the total volume of potassium, phosphorus, calcium, magnesium, sodium, iron, copper, zinc, and aluminium.

\section{Kjeldahl and Dummas Methods}

Kjeldahl Method is a complex process to determine the total value of nitrogen $(\mathrm{N})$ because there are many forms of nitrogen $(\mathrm{N})$ such as ammonium $\left(\mathrm{NH}_{4}+\right)$, nitrate $\left(\mathrm{NO}_{3}-\right)$, nitrite $\left(\mathrm{NO}_{2}\right)$ and others. Firstly, the sample was digested in a concentrated sulphuric acid with a catalyst mixture in order to increase the boiling temperature and to promote the conversion of organic-N to ammonium-N. Secondly, throughout the process, the ammonium-N from the digest was obtained through a steam distillation by using excessive sodium hydroxide $(\mathrm{NaOH})$ to raise the $\mathrm{pH}$ value. The distillate was collected in a saturated boric acid and titrated with dilute sulphuric acid to a $\mathrm{pH}$ value of 5.0.

After that, the experiment was continued with Dummas Method. A dry $250 \mathrm{~mL}$ Erlenmeyer flask with an aluminium foil cap was weighed with a digital analytical balance. In this experiment, the sample must be in a liquid form with "low" vapour pressure at room temperature. Then, $10 \mathrm{ml}$ of distilled water was added onto the sample. The sample underwent a heating process by applying heat until the temperature reached $100^{\circ} \mathrm{C}$. In this process, if the amount of distilled water added was not appropriate, the vapour would not completely displace the air. However, if an 
excessive amount of distilled water was added, it would take a longer time to completely evaporate the sample. After the liquid had all been boiled off, the heating process was continued for 2-3 minutes to ensure the temperature of the vapour in the flask was the same as the temperature of the boiling water. When the reading of boiling water and vapour temperatures reached at the same value, the flask was quickly carefully cooled down under the running water while avoiding water spillage into the flask. Besides that, the flask must not be cooled down to a point below the dew point as the results would be affected. Finally, the outside of flask was quickly dried up (Buckee, 1994). The dried sample was sent to the DUMATHERM Machine (DUMATHERM, Gerhart Analytical System, $\mathrm{UK})$ to determine the value of Nitrogen $(\mathrm{N})$ in A. pinnata.

\section{Statistical Analysis}

A Duncen's test was performed using IBM SPSS Statistics 21.0 to differentiate and evaluate the significance between the mean values. The confidence limit was considered as 95\% ( $\mathrm{p}<0.05)$. The values were stated as the mean \pm standard deviation.

\section{Results \& Discussion}

\section{Single Dry Ashing Method}

\section{Determination of total macro-nutrients (phosphorus, $\mathbf{P}$ and potassium, $\mathrm{K}$ )}

Table (1) shows the results obtained from the Single Dry Ashing method. Using this method, the results included macronutrient comprised of phosphorus and potassium, and micronutrients including calcium, magnesium, sodium, iron, copper, zinc, and aluminium.

Firstly, focusing on the macronutrient results, according to the result in table (1), Azolla (4352.00 ppm) had the highest value of phosphorus compared to Midorie Pafcal
(377.13 ppm) and Jiffy-7 pallet (563.13 ppm). The difference in Phosphorus between in Azolla and Midorie Pafcal was 3974.87 ppm and between Azolla and Jiffy-7 pallet was $3788.87 \mathrm{ppm}$, however without any statistical significance $\quad(p>0.05 ; 90 \%$ and $87 \%$, respectively). Phosphorus was one of the essential nutrients needed by plants. It helps plants to convert other nutrients into usable building blocks with which to grow (Rhoades, .n.d.). If the plants receives low amount of phosphorus, it might produce a plant that is small in size and having minimal amount of flowers, and weak root system or bright green or purplish cast (Rhoades, .n.d.). Table (1) also shows that the Azolla sample had the highest value for potassium compared to that of Midorie Pafcal and Jiffy-7 pallet. Azolla contained $13873.33 \mathrm{ppm}$ of potassium which was $12361.00 \mathrm{ppm}$ more compared to Midorie Pafcal and 12529.66 ppm compared to Jiffy-7 pallet. Midorie Pafcal and Jiffy-7 pallet contained $1512.33 \mathrm{ppm}$ and $1343.67 \mathrm{ppm}$ of potassium, respectively. The difference in the potassium content in Azolla, Midorie Pafcal and Jiffy-7 pallet was not statistically significant $(p>0.05)$ which were about $89 \%$ to $90 \%$. Based on a previous related study, Azolla was used as a growing media for nursery olive trees. In this study, the Azolla was analyzed for macronutrients, comprising of nitrogen, phosphorus, and potassium, and for micronutrients, which were calcium and magnesium, in leaves, stems and roots. The results showed statistically significant differences but these were minimal in tissues between the four substrates (GMC: $50 \%$ Peat $+50 \%$ Pumice, GM1: $25 \%$ Peat $+25 \%$ Azolla + 50\% Pumice, GM2: 50\% Azolla + 50\% Pumice and GM3: 100\% Azolla) (Petruccelli, et al., 2015).

Besides phosphorus, potassium is also a common macronutrient needed by plants. 
Shamsudin et al. / Basrah J. Agric. Sci., 34(Special Issue 1): 180-189, 2021

Potassium should be supplied by soil or growth media to ensure that the plants could grow in the right conditions. Potassium has a mitigating role in various abiotic stresses such as drought, salinity, metal toxicity, and high or chilling temperature. It also functions as a regulator in the seed germination phase and the emergence process, photosynthesis process and stress resistance. The minimal difference in values showed that Azolla was suitable to use as growing media.

\section{Determination of total micro-nutrients (calcium, magnesium, sodium, iron, copper, zinc and aluminium)}

Using the dry ashing method, the results for micronutrients such as calcium, magnesium, sodium, iron, copper, zinc, and aluminium for Azolla were also obtained: $8066.00 \mathrm{ppm}$, 3613.00 ppm, 3384.00 ppm, 2579.67 ppm, $15.33 \mathrm{ppm}, 93.63 \mathrm{ppm}$, and $13916.67 \mathrm{ppm}$, respectively. In Midorie Pafcal, the values of all the results were as follows: $3728.00 \mathrm{ppm}$, 1372.67 ppm. 125.50 ppm, 9988.33 ppm, 7.53 ppm, 26.77 ppm, and $11260.00 \mathrm{ppm}$, respectively. As for the Jiffy-7 pallet, the results were as follows: $17651.67 \mathrm{ppm}$, $1282.67 \mathrm{ppm}, 211.50 \mathrm{ppm}, 1150.30 \mathrm{ppm}$, $13.01 \mathrm{ppm}, 12.40 \mathrm{ppm}$, and $964.33 \mathrm{ppm}$. According to the results obtained, the difference $(p>0.05)$ between all micronutrients values ranged from $7.6 \%$ to $99 \%$. In the olive trees study, the values for calcium and magnesium were obtained as micronutrients. The results showed that the value of calcium and magnesium in the Azolla sample was statistically significant with a minimal difference in all tissues between the four substrates tested (Petruccelli et al., 2015). Based on results tabulated in table (1), it can be concluded that the Azolla had achieved the highest value on most of the macro and micronutrients tested except for iron, which was highest in Midorie Pafcal, and calcium, which was highest in Jiffy-7 pallet.

\section{Kjeldahl and Dummas Methods}

\section{Determination of total macro-nutrient (nitrogen, $\mathbf{N}$ )}

Table (2) shows the results obtained from the Kjeldahl and Dummas methods. The results obtained included the macronutrient which was nitrogen and micronutrients, which were carbon and sulphur. According to table (2), for the total value of nitrogen, the Midorie Pafcal had the highest percentage $(1.35 \%)$ and followed by the Azolla (0.94\%) while the Jiffy-7 pallet did not contain nitrogen. The difference of nitrogen value in Azolla and Midorie Pafcal pallet was significant since Midorie Pafcal had 43\% more nitrogen content compared to Azolla. The difference of nitrogen value of Azolla and Jiffy-7 pallet was not significant with minimal different $(p>0.05)$ with $100 \%$.

By comparing to the previous study, the result obtained from Azolla as growing media for olive trees was attributed to higher $\mathrm{N}$ concentration in the Azolla dry-biomass (5.0\%) (Petruccelli et al., 2015). The total percentage of nitrogen in a plant is associated with the component of both organic and inorganic. The total value of nitrogen is the sum of nitrate $\left(\mathrm{NO}_{3}\right)$, nitrite $\left(\mathrm{NO}_{2}\right)$, organic nitrogen, and ammonia (all expressed as $\mathrm{N}$ ). 
Shamsudin et al. / Basrah J. Agric. Sci., 34(Special Issue 1): 180-189, 2021

Table (1): The average total value of phosphorus (P), potassium (K), calcium (Ca), magnesium (Mg), sodium (Na), iron (Fe), copper (Cu), zinc ( $\mathrm{Zn})$ and aluminium (Al)

\begin{tabular}{|c|c|c|c|c|c|c|c|c|c|}
\hline \multirow[b]{2}{*}{ Samples } & \multicolumn{9}{|c|}{ ppm } \\
\hline & (P) & $(\mathrm{K})$ & (Ca) & $(\mathrm{Mg})$ & $(\mathrm{Na})$ & $(\mathrm{Fe})$ & $(\mathrm{Cu})$ & $(\mathrm{Zn})$ & (Al) \\
\hline Azolla & 4352.0 & 13873.33 & 8066.00 & 3613.00 & 3384.00 & 2579.67 & 15.33 & 93.63 & 13916.67 \\
\hline $\begin{array}{l}\text { Midorie } \\
\text { Pafcal }\end{array}$ & $\begin{array}{c}377.13 \\
( \pm 3974.9)^{\mathrm{a}}\end{array}$ & $\begin{array}{c}1512.33 \\
( \pm 12361.0)^{a}\end{array}$ & $\begin{array}{c}3728.00 \\
( \pm 4338.0) \\
a\end{array}$ & $\begin{array}{c}1372.67 \\
( \pm 2240.3) \\
a\end{array}$ & $\begin{array}{c}125.10 \\
( \pm 3258.9) \\
a\end{array}$ & $\begin{array}{c}9988.33 \\
( \pm 7408.7)\end{array}$ & $\begin{array}{c}7.53 \\
( \pm 7.8)^{\mathrm{a}}\end{array}$ & $\begin{array}{c}26.77 \\
( \pm 66.9)^{\mathrm{a}}\end{array}$ & $\begin{array}{c}11260.00 \\
( \pm 2656.7)^{a}\end{array}$ \\
\hline $\begin{array}{l}\text { Jiffy-7 } \\
\text { Pallet }\end{array}$ & $\begin{array}{c}563.13 \\
( \pm 3788.9)^{\mathrm{a}}\end{array}$ & $\begin{array}{c}1343.67 \\
( \pm 12529.7)^{a}\end{array}$ & $\begin{array}{c}17651.67 \\
( \pm 6298.3) \\
a\end{array}$ & $\begin{array}{c}1282.67 \\
( \pm 2330.3) \\
a\end{array}$ & $\begin{array}{c}211.50 \\
( \pm 3172.5) \\
a\end{array}$ & $\begin{array}{c}1150.30 \\
( \pm 1429.4) \\
a\end{array}$ & $\begin{array}{c}13.01 \\
( \pm 3172.5)^{\mathrm{a}}\end{array}$ & $\begin{array}{c}12.40 \\
( \pm 9350.6) \\
a\end{array}$ & $\begin{array}{c}964.33 \\
( \pm 12952.3)^{a}\end{array}$ \\
\hline
\end{tabular}

Means followed by same letter do not differ significantly at $\mathrm{P}<0.05$ (Duncan's Test). 
The major forms of inorganic nitrogen are $\mathrm{N}_{2}$ gas, nitrate, nitrite, and ammonium. The presence of organic nitrogen can be identified through numerous forms such as amino acids, proteins, nucleic acids, nucleotides, and urea (Murdock et al., 2010). In conclusion, the total value of carbon, sulphur, and total $\mathrm{N}$ of the Azolla was greater than that of Midorie Pafcal but lower than that of the Jiffy-7 pallets. While the sulphur deficiency symptoms on an individual leaf look like those of nitrogen deficiency symptoms, the latter typically begins in the weakest leaves, not of the newest (Bloodnick, 2018).

\section{Determination of total micro-nutrient (carbon, $\mathrm{C}$ and sulphur, S)}

Based on table (2), the total value of carbon and sulphur is tabulated for the raw A. pinnata, Midorie Pafcal, and Jiffy-7 pallet. Table (2) indicates that the carbon value in the $A$. pinnata was $36.68 \%$ less compared to that of Jiffy-7 pallet $(41.44 \%)$. The carbon value in Midorie Pafcal was $32.47 \%$. The difference of carbon content between Azolla and Midorie Pafcal was not significant $(\mathrm{p}=11 \%)$, but the result between Azolla and Jiffy-7 pallet was statistically significant $(\mathrm{p}<0.05)$. The other findings found no results related to carbon and sulphur values.

Carbon in plants is used to create healthier plants. Some would be converted into carbon dioxide, which would aid the photosynthesis process and eventually be released into the atmosphere. However, some of the carbon would be locked in the soil. When a plant dies, carbon dioxide is be given off from the decomposition of the plant. The role of carbon in plants is to foster healthier plants, as well as to increase the productive growth of the plants (Grant,.n.d.). A. pinnata contained the highest percentage of sulphur with $0.20 \%$, followed by Jiffy-7 pallet $(0.13 \%)$ and Midorie Pafcal $(0.11 \%)$. Sulphur is one of the three secondary nutrients required by plants for a normal and healthy growth along with calcium and magnesium. Sulphur is a vital part of all plants' proteins and certain plants' hormones. Sulphur is also associated with the formation of proteins and chlorophyll. The effect of sulphur deficiency might resemble those of nitrogen symptoms deficiency. The deficiency symptoms usually start on the younger leaves and progress over time to the older leaves, resulting in plants becoming uniformly chlorotic.

Table (2): The average of total percentage value of carbon, sulphur and total $\mathrm{N}(\%)$.

\begin{tabular}{cccc}
\hline Samples & Carbon & Sulphur & Total N \\
\hline A. pinnata & $36.68^{\mathrm{a}}$ & $0.20^{\mathrm{a}}$ & $0.94^{\mathrm{a}}$ \\
\hline Midorie Pafcal & $32.47^{\mathrm{a}}$ & $0.11^{\mathrm{a}}$ & 1.35 \\
\hline Jiffy-7 Pallet & 41.44 & $0.13^{\mathrm{a}}$ & $0.00^{\mathrm{a}}$ \\
\hline
\end{tabular}

Means followed by same letter do not differ significantly at $\mathrm{P}<0.05$ (Duncan's Test).

\section{Determine the total value of nitrate ( $\left.\mathrm{NO}_{3}-\right)$ and ammonium $\left(\mathrm{NO}_{4+}\right)$}

Table (3) contains the information regarding the value of nitrate $\left(\mathrm{NO}_{3}-\right)$ and ammonium
$\left(\mathrm{NH}_{4}+\right)$. The value of nitrate $\left(\mathrm{NO}_{3}-\right)$ and ammonium $\left(\mathrm{NH}_{4}+\right)$ was calculated using the ppm unit. For the nitrate $\left(\mathrm{NO}_{3}-\right)$ value, the $A$. pinnata had the highest value $(8610.63 \mathrm{ppm})$ compared to that of Midorie Pafcal (3277.29 
Shamsudin et al. / Basrah J. Agric. Sci., 34(Special Issue 1): 180-189, 2021

ppm) and Jiffy-7 pallet (4610.63 ppm). The results showed that Azolla was capable to supply nitrates for plants to grow. Plants use nitrates which supplies the nitrogen required to make proteins for a healthy growth. Plants absorb nitrates in the water through their roots (Hewitson, .n.d.). Without nitrates, the amount of chlorophyll in leaves would be reduced. The results obtained in table (3) showed the value of nitrate in Azolla was not significant with about $50 \%$ and $62 \%$ more than that of in Midorie Pafcal and Jiffy-7 pallet, respectively. Without nitrates, the leaves would turn into a pale green or yellow colour. This would reduce the plant's ability to photosynthesise and grow properly. All forms of nitrates would add nitrogen to the soil. However, some are more soluble than others, and thus, would produce more or fewer nitrate ions in the soil solution (Hewitson, .n.d.). As for the ammonium $\left(\mathrm{NH}_{4}+\right)$ value, Azolla had the lowest value
(1943.96 ppm) compared that of Midorie Pafcal (3277.29 ppm) and Jiffy-7 pallet (3943.96 ppm). Ammonium is considered as a cation (positively charged ion), and therefore, it competes with other cations such as potassium, calcium, and magnesium for uptake by the roots. Unbalanced fertilization, with too high ammonium content, might result in calcium and magnesium deficiencies. Potassium uptake was less affected by the competition. Ammonium to nitrate ratio might change the value of $\mathrm{pH}$ near the roots. These $\mathrm{pH}$ changes might affect the solubility and availability of other nutrients. For an optimal uptake and growth, each plant species requires a different ammonium: nitrate ratio. The correct ratio also varies with the temperature, growth stage, $\mathrm{pH}$ in the root zone, and soil properties. As a conclusion, the raw Azolla did contain nitrate $\left(\mathrm{NO}_{3}-\right)$ and ammonium $\left(\mathrm{NH}_{4}+\right)$ which are important to soil or growth media.

Table (3): The average total value of nitrate ( $\left.\mathrm{NO}_{3}-\right)$ and ammonium $\left(\mathrm{NH}_{4+}\right)$. Means followed by same letter do not differ significantly at $\mathrm{P}<0.05$ (Duncan's Test).

\begin{tabular}{ccc}
\hline Samples & \multicolumn{3}{c}{ ppm } \\
\cline { 2 - 3 } & $\begin{array}{c}\text { Nitrate } \\
(\mathrm{NO3}-)\end{array}$ & $\begin{array}{c}\text { Ammonium } \\
(\mathrm{NH} 4+)\end{array}$ \\
\hline A. pinnata & $8610.63^{\mathrm{a}}$ & $1943.96^{\mathrm{a}}$ \\
\hline Midorie Pafcal & 3277.29 & 3277.29 \\
& $( \pm 5333.34)^{\mathrm{a}}$ & $( \pm 1333.33)$ \\
\hline Jiffy-7 Pallet & 4610.63 & 3943.96 \\
& $( \pm 4000.00)^{\mathrm{a}}$ & $( \pm 2000.00)$ \\
\hline
\end{tabular}

\section{Conclusion}

The samples were tested with two different methods to analyse several aspects to ensure the appropriate amount of data and information were collected and tabulated. The analyses performed on the samples primarily focused on comparing the macro and micronutrients between A. pinnata sp.,
Midorie Pafcal and Jiffy-7 pallets as a growth media. For raw A. pinnata, it has been proven that the plant had all the initial nutrients needed for the growth development of ornamental plants. The raw $A$. pinnata sp. was observed to contain $4352.00 \mathrm{ppm}$ of phosphorus (P), 13873.33 
ppm of potassium $(\mathrm{K}), 8066.00 \mathrm{ppm}$ of calcium $(\mathrm{Ca}), 3613.00 \mathrm{ppm}$ of magnesium $(\mathrm{Mg}), 3384.00 \mathrm{ppm}$ of sodium $(\mathrm{Na})$, $2579.67 \mathrm{ppm}$ of iron $(\mathrm{Fe}), 15.33 \mathrm{ppm}$ of copper $(\mathrm{Cu}), 93.63 \mathrm{ppm}$ of zinc $(\mathrm{Zn})$, and $13916.67 \mathrm{ppm}$ of aluminium (Al). In conclusion, the total value of phosphorus, potassium, calcium, magnesium, nitrogen, iron, copper, zinc, and aluminium of $A$. pinnata was greater than the existing products, Midorie Pafcal and Jiffy-7 pallet.

\section{Conflict of interest}

All authors did not have any conflict of interest.

\section{Acknowledgement}

Special thanks to the Universiti Putra of Malaysia for providing the essential financial and technical support to conduct this particular research. The authors would also like to take this opportunity to acknowledge Pertubuhan Peladang Kawasan Bachok, Kelantan and Lembaga Pertubuhan Peladang (LPP) for their contribution in this research study.

\section{References}

Ali, M. A., \& S. Leeson, S. (1995). The nutritive value of some indigenous Asian poultry feed ingredients. Animal Feed Science and Technology, 55, 227-237. https://doi.org/10.1016/0377-8401(95)00801-S

Argo, W. R. (1998). Root medium chemical properties. HorTtechnology, 8(4), 486-494. https://doi.org/10.21273/HORTTECH.8.4.486

Bloodnick, E. (2018). Role of copper in plant culture. PRO-MIX Greenhouse Growing, Quebec.

https://www.pthorticulture.com/en/trainingcenter/role-of-copper-in-plantculture/\#: :text=Copper\%20activates\%20some $\% 20$ enzymes\%20in,metabolism\%20of\%20 carb ohydrates $\% 20$ and $\% 20$ proteins
Bragg, N., (1998). Grower Handbook 1: Growing Media. Nexus, Kent, UK. 112pp.

Brouwer, P., Schluepmann, H., Nierop, K. G., Elderson, J., Bijl, P. K., van der Meer, I., ... \& van der Werf, A. (2018). Growing Azolla to produce sustainable protein feed: the effect of differing species and $\mathrm{CO} 2$ concentrations on biomass productivity and chemical composition. Journal of the Science of Food and Agriculture, 98(12), 4759-4768. https://doi.org/10.1002/jsfa.9016

Brouwer, P., Nierop, K. G., Huijgen, W. J., \& Schluepmann, H. (2019). Aquatic weeds as novel protein sources: Alkaline extraction of tannin-rich Azolla. Biotechnology Reports, 24, e00368.

https://doi.org/10.1016/j.btre.2019.e00368

Buckee, G. K. (1994). Determination of total nitrogen in barley, malt and beer by Kjeldahl procedures and the dumas combustion methodcollaborative trial. Journal of the Institute of Brewing, 100(2), 57-64. https://doi.org/10.1002/jib.1994.100.2.57

Bunt A. C. (1988), Physical aspects. In: Media and Mixes for Container- Grown Plants. Springer, Dordrecht. https://doi.org/10.1007/978-94-0117094-1_3

Croft, J. R. (1986). Azollaceae. (http://www.anbg.gov.au/projects/fern/aquatic/ azollaceae.html). [15 November 2002, last accessed].

Han, H. S., \& Lee, K. D. (2005). Phosphate and potassium solubilizing bacteria effect on mineral uptake, soil availability and growth of eggplant. Research Journal of Agriculture and Biological Sciences, 1(2), 176-180. http://www.aensiweb.net/AENSIWEB/rjabs/rja bs/176-180.pdf

Handreck, K. A., \& Black, N., (1994). Growin media for ornamental plants and turf. 2nd edition (Revised ed.), UNSW Press, Sydney. https://www.abebooks.com/servlet/BookDetail sPL?bi=30935522318\&searchurl=an\%3Dkevi n\%2Bhandreck\%26sortby\%3D17\%26tn\%3Dg rowing\%2Bmedia\%2Bornamental\%2Bplants\& cm_sp=snippet-_-srp1-_-title2 
Krucker, M., Hummel, R. L., \& Cogger, C. (2010). Chrysanthemum production in composted and noncomposted organic waste substrates fertilzed with nitrogen at two rates using surface and subirrigation. HortiSciencehorts, 55(11), 1695-1701.

https://doi.org/10.21273/HORTSCI.45.11.1695

Lemaire, F. (1995). Physical, chemical and biological properties of growing medium. Hydroponics and Transplant Production 396, 273-284. https://doi.org/10.17660/ActaHortic.1995.396. 33

Liu, L., Peng, B., Yue, C., Guo, M., \& Zhang, M. (2019). Low-cost, shape-stabilized fly ash composite phase change material synthesized by using a facile process for building energy efficiency. Materials Chemistry and Physics, 222, 87-95. https://doi.org/10.1016/j.matchemphys.2018.0 9.072

Lucas, R. E., \& Davis, J. (1961). Relationships between $\mathrm{pH}$ values of organic soils and availabilities of 12 plant nutrients. Soil Science, 92(3), 177-182. https://doi.org/10.1097/00010694-19610900000005

Michel, J. -C. (2010). The physical properties of peat: a key factor for modern growing media.Mires and Peat,6(2), non-paginé. https://hal-agrocampus-ouest.archivesouvertes.fr/file/index/docid/729716/filename/ map_06_02.pdf

Murdock, J. N., Gido, K. B., Dodds, W. K., Bertrand, K. N., \& Whiles, M. R. (2010). Consumer return chronology alters recovery trajectory of stream ecosystem structure and function following drought. Ecology, 91(4), 1048-1062. https://doi.org/10.1890/08-2168.1

Nichols, M. (2013). COIR: Sustainable growing media.http://www.planetcococoir.com/sustaina ble-growing-media.php (accessed 26.09.21).

Petruccelli, R., Bati, C. B., Carlozzi, P., Padovani, G., Vignozzi, N., \& Bartolini, G. (2015). Use of Azolla as a growing medium component in the nursery production of olive trees. International Journal of Basic and Applied Sciences, 4(4), 333. https://doi.org/10.14419/ijbas.v4i4.4660
Prasad, M. (1996). Physical, chemical and biological properties of coir dust. In International Symposium Growing Media and Plant Nutrition in Horticulture, 450, 21-30. https://doi.org/10.17660/ActaHortic.1997.450. 1

Robertson, R. A. (1993). Peat, horticulture and environment. Biodiversity \& Conservation, 2(5), 541-547. https://link.springer.com/content/pdf/10.1007/ BF00056747.pdf

Schmilewski, G. (2008). The role of peat in assuring the quality of growing media. Mires \& Peat, 3. Art. 2. http://www.mires-andpeat.net/pages/volumes/map03/map0302.php

Silber, A. (2008). Chapter 6: Chemical characteristics of soilless media. 209-244. In: Raviv, M., \& Leith, H. (Eds.). Soilless culture, Theory and practice. Elsevier Science, Academic Press. 608pp. https://www.elsevier.com/books/soillessculture-theory-and-practice/raviv/978-0-44452975-6

Soo, R. M., Hemp, J., \& Hugenholtz, P. (2019). Evolution of photosynthesis and aerobic respiration in the cyanobacteria. Free Radical Biology and Medicine, 140, 200-205. https://doi.org/10.1016/j.freeradbiomed.2019.0 3.029

Wagner, G. M. (1997). Azolla: A review of its biology and utilization. The Botanical Review, 63(1), 1-26. https://doi.org/10.1007/BF02857915 